\title{
Path Analysis on the Biopsychosocial Determinants and Genital Hygiene on Cervical Cancer at Dr. Moewardi Hospital, Surakarta, Central Java
}

\author{
Afriza Umami'1), Setyo Sri Rahardjo²), Bhisma Murti1) \\ 1)Masters Program in Public Health, Universitas Sebelas Maret \\ ${ }^{2)}$ Faculty of Medicine, Universitas Sebelas Maret
}

\begin{abstract}
Background: Cervical cancer is the fourth most common cancer in women worldwide and the second most common cancer in women in developing countries after breast cancer. The prevalence of cervical cancer in Indonesia was $0.8 \%$ with an estimated 98.692 cases. This study aimed to determine the biopsychosocial and genital hygiene factors on cervical cancer.

Subjects and Method: This was an analytic observational study with a case-control design, conducted at Dr. Moewardi Hospital, Surakarta, from December 2017 to February 2018. A total of 178 study subjects including 95 women with cervical cancer (case) and 83 women without cervical cancer (control) were selected by fixed disease sampling. The dependent variable was cervical cancer. The independent variables were an age at first sexual intercourse, the number of sexual partners, body mass index (BMI), stress, education, income, and genital hygiene. Cervical cancer data was collected by medical record. The other data were collected by questionnaire. The data were analyzed by path analysis model.

Results: The risk of cervical cancer increased with the number of sexual partner $>1(b=1.91 ; 95 \%$ $\mathrm{CI}=0.31$ to $3.49 ; \mathrm{p}=0.019), \mathrm{BMI} \geq 25(\mathrm{~b}=0.98 ; 95 \% \mathrm{CI}=-0.06$ to $2.04 ; \mathrm{p}=0.067)$, and stress $(\mathrm{b}=$ $1.59 ; 95 \% \mathrm{CI}=0.39$ to $2.80 ; \mathrm{p}=0.009)$. The risk of cervical cancer decreased with higher education $(b=-3.58 ; 95 \% \mathrm{CI}=-4.77$ to $-2.39 ; \mathrm{p}<0.001)$, higher income $(\mathrm{b}=-1.49 ; 95 \% \mathrm{CI}=-2.73$ to $-0.25 ; \mathrm{p}=$ $0.019)$, age at first sexual intercourse $\geq 18$ years $(b=-1.36 ; 95 \% \mathrm{CI}=-2.52$ to $-0.21 ; \mathrm{p}=0.020)$, and genital hygiene $(b=-1.24 ; 95 \% \mathrm{CI}=-2.35$ to $-0.13 ; \mathrm{p}=0.028)$. Income increased with higher education $(b=2.48 ; 95 \% \mathrm{CI}=1.71$ to $3.25 ; \mathrm{p}<0.001)$. Genital hygiene increased with education $(\mathrm{b}=$ $1.16 ; 95 \% \mathrm{CI}=0.47$ to $1.86 ; \mathrm{p}=0.001)$. Age at first sexual intercourse $\geq 18$ years increased with higher education ( $b=1.30 ; 95 \% \mathrm{CI}=0.58$ to $2.01 ; \mathrm{p}<0.001)$. Stress increased with number of sexual partner $>1(b=1.36 ; 95 \% \mathrm{CI}=0.12$ to $2.61 ; \mathrm{p}=0.032)$.

Conclusion: The risk of cervical cancer increases with the number of sexual partners, BMI, and stress, but decreases with higher education, higher income, age at first sexual intercourse, and genital hygiene.
\end{abstract}

Keywords: cervical cancer, biopsychosocial determinants, genital hygiene, path analysis

\section{Correspondence:}

Afriza Umami. Masters Program in Public Health, Universitas Sebelas Maret, Jl. Ir. Sutami 36 A, Surakarta, Central Java. Email: afrizaumami20@gmail.com. Mobile: +6282254348041.

\section{BACKGROUND}

$\overline{\text { Cancer is one of the biggest causes of illness }}$ and death worldwide. Based on data from the International Agency for Research on Cancer (IARC), in 2012, there were about 14 million new cases of cervical cancer worldwide (Ferlay et al., 2013; Torre and Siegel, 2015). Globally, nearly 1 in 6 deaths are caused by cancer. About $70 \%$ of cancer deaths occur in low and middle-income countries (WHO, 2017). Cancers caused by viral infections, such as Hepatitis and 
Journal of Epidemiology and Public Health (2018), 3(2): 277-291

https://doi.org/10.26911/jepublichealth.2018.03.02.07

Human Papilloma Virus (HPV), account for about $25 \%$ of cancer cases in low and middle-income countries (Plummer et al., 2016).

Human papilloma virus (HPV) is the causative agent of almost all cases of cervical cancer, HPV can infect the genital area of women and men, including the skin of the vulva, penis, and anus; lining of the vagina, cervix, and rectum; and lining the mouth and throat. Unlike other sexually transmitted infections, most signs and symptoms of HPV are absent, so most individuals are unaware of infection (Kessler, 2017).

Cervical cancer is the fourth most common cancer in women worldwide (Basu et al., 2017). Based on data from the International Agency for Research on Cancer (IARC) in 2012, women diagnosed with cervical cancer were 527,624 cases and 265,672 died from the disease (Basu et al., 2017; Bruni et al., 2017). Deaths from cervical cancer account for nearly $85 \%$ of whom are in low to middle-income countries (WHO, 2016) and still pose a serious threat to women's lives (Hope et al, 2017).

Cervical cancer is the second most commonly diagnosed cancer in developing countries after breast cancer, it is for about $12 \%$ of all cancers in women (Basu et al., 2017) and represents $7.5 \%$ of all cancer deaths in women (WHO, 2016). The prevalence of cervical cancer in the Asian region caused by HPV is $9 \%$ with an estimated case of 284,823 , while the Southeast Asia case estimation is 50,566 (Ferlay et al., 2013; Bruni et al., 2017). Cervical cancer in Indonesia was in the second place with a new case number of 20.928 with a mortality rate of 10.3 per 100,000 women in 2012 (WHO, 2014).

Cervical cancer was the highest prevalence of cancer in Indonesia in 2013.
The prevalence of cervical cancer was 0.8 \%o with an estimated absolute number of 98,692 patients. Based on the estimated number of cervical cancer patients in the province of East Java and Central Java Province, cervical cancer patients in Central Java Province was about 1.2 \%o with an estimated absolute amount of 19.734 (Ministry of Health RI, 2015).

Poor genital hygiene causes the development of fungi, viruses, and bacteria in the genital organs. It eases the transmission of HPV viruses to the genital organs. If someone is not able to maintain cleanliness of vaginalis organs then it is very possible that that person will be infected with HPV virus. HPV virus infection indicates that the immune system in the body is weakened, which will cause the growth of cancer cells to increase (Chelimo et al., 2013; Natphopsuk et al., 2013).

Women who have early sexual intercourse or have multiple sexual partners are at high risk for HPV infection and cervical cancer (Ali et al., 2016; Kessler, 2017). Cervical cancer problems will disrupt the continuity of harmony, especially in sexual influences so that patients with cervical cancer will feel fear, anxiety, and sadness in the face of a family (Videbeck, 2008). Problems of anxiety, depression, and stress can lead to metaplasia of cancer cells quickly. If cancer patients are in a state of stress, it will speed up the development of cancer cells (Song et al., 2017; Lu, 2017).

Women with low incomes who have limited access to health care possibly have never done any screening (Kessler, 2017). Cervical cancer can be detected at stage I or II with routine pap smear tests, with slow growth resulting in women not experiencing symptoms until the next stage of manifestation until conditions worsen (Roy 
\& Tang, 2008). Although screening with Pap smear technology has reduced the disease case, cervical cancer remains the second most common cause of cancer deaths among women worldwide (Lowy et al., 2008). The high prevalence of cervical cancer should be resolved immediately by using an approach model capable of assessing various factors related either directly or indirectly.

Dr. Moewardi Regional General Hospital is a Class A Hospital and National Referral Hospital. Based on data obtained from the hospital medical record in Moewardi hospital, it can be seen that the number of outpatient visit of cervical cancer always increases every year. The number of patient visits both old and new cervical cancer in 2016 was 6,515 visits, and in 2017 to October it was about 4,982 visits. Cervical cancer is included in the 3 major most hospitalized diseases in Dr. Moewardi hospital. Cervical cancer is also the first highest disease in obstetrics and gynecology in Dr. Moewardi hospital.

Based on this background and the high number of women suffering from cervical cancer, the researchers are interested to examine more about the factors that affect the incidence of cervical cancer, especially in analyzing the determinants of biopsychosocial and genital hygiene to the cervical cancer cases in Dr. Moewardi Hospital, Surakarta. The health biopsychosocial model is a model used to describe biological, psychological and social factors. Determination of disease determinants based on biological causes is not sufficient to explain the occurrence of disease processes in the body (Murti, 2016).$$
\text { SUBJECTS AND METHOD }
$$$$
\text { 1. Study Design }
$$

This was an analytic observation study with a case of control study. According to the
}

type, it was based on the chronological timing using retrospective study. The study was conducted in Dr. Moewardi hospital, Surakarta, from December 2017 to February 2018.

\section{Population and Sample}

The source population used in this study was cervical cancer patients who underwent treatment at Dr. Moewardi hospital Surakarta. The case group was cervical cancer patients who underwent treatment at Dr. Moewardi hospital both in outpatient and inpatient as much. While the control population was a patient other than cervical cancer who underwent treatment at Dr. Moewardi hospital which was about 83 subjects. It used fixed disease sampling technique.

\section{Study Variables}

The dependent variable was cervical cancer. The independent variables included education, income, age when having sexual intercourse, number of sexual partners, Body Mass Index, stress, and genital hygiene.

\section{Operational Definition of Variables}

Cervical cancer is cancer suffered by patients who have been diagnosed by a doctor based on anamnesis, physical examination, screening results or histopathology tissue biopsy. Education is the highest level of formal education taken by women before being diagnosed with cervical cancer. Income is a condition that describes the income of a husband, wife or family member obtained per month. The first age of sexual intercourse is the age of the subject the first time they have sexual intercourse either before or after marriage. The number of sexual partners is the sexual activity of the study subject with the alternating sexual partner. Body Mass Index (BMI) is the nutritional state of the study subjects as measured by BMI according to the WHO standard before being diagnosed with cervical cancer. Stress is assessing how the 
Journal of Epidemiology and Public Health (2018), 3(2): 277-291

https://doi.org/10.26911/jepublichealth.2018.03.02.07

emotions of the subjects whether it is unpredictable, unable to control everything, and feeling full of burden in their lives before being diagnosed with cervical cancer with Perceived Stress Scale Questionnaire (PSS). Genital hygiene is an action in maintaining the cleanliness of female genitals, both at the time of menstruation, before and after sexual intercourse and daily hygiene such as how to clean the genitals after urination and use of condoms in a partner before being diagnosed with cervical cancer.

\section{Study Instruments}

The study instrument used for data collection was the questionnaire. The validity tests included the content validity and face validity. The reliability test was conducted on 20 patients who underwent treatment at Dr. Moewardi hospital, Surakarta. The reliability test was performed by measuring the variables using the SPSS 22 statistical program which can calculate the total-item correlation $(\geq 0.20)$ and Cronbach alpha $(\geq 0.70)$.

\section{Data Analysis}

The data analysis used path analysis with program Stata 13 to know the influence of determinant influence, either direct or indirect influences. The steps of path analysis in this study were the model specification, model identification, model compatibility, parameter estimation and model re-spesification.

\section{Research Ethics}

Research ethics included informed consent, anonymity, confidentiality, and ethical clearance. Ethical clearance in this study was conducted at Dr. Moewardi hospital Surakarta.

\section{RESULTS}

1. The Characteristics of Subjects

The characteristics of subjects in the group of cases were 95 subjects and the control groups were 83 subjects. The frequency distribution of subject characteristics is described in Table 1.

Table 1 shows that a small proportion of the study subjects was not attending school for about 14 subjects (7.9\%). Family income obtained by most subjects is low for about 118 research subjects (66.3\%). The age of the first sexual intercourse in the subjects was mostly over the age of 18 years for about 125 subjects (70.2\%).

Meanwhile, most of the subjects have one sexual partner which was about 150 subjects (78.0\%). Some study subjects' BMI were obese for about 27 subjects (15.2\%). Related to the stress perception score on the subjects, some suffered severe stress for about 16 subjects (9\%). Most subjects have good genitalia hygiene behavior of 122 subjects (68.5\%).

\section{Path Analysis}

The data processing used Stata 13 program. Pathway analysis steps were model specification, model identification, parameter estimation and model respesification. The number of measured variables were 8,5 endogenous variables, and exogenous variables were 3 . So, the degree of freedom (df): 25. Then, it can be concluded that it was df over identified which means that the path analysis can be done.

The structural model with estimation is shown in Figure 1 and the path analysis results are shown in Table 2. The model in this study was in accordance with the sample data shown by the saturation model and also the regression coefficient which is worth more than zero and has been statistically significant, it does not need to be regenerated.

Table 3 shows high education decreased the risk of cervical cancer $(b=$ $3.58 ; 95 \% \mathrm{CI}=-4.77$ to -2.39 ; $\mathrm{p}<0.001$ ). 
Table 1. The Characteristics of Study Subjects

\begin{tabular}{|c|c|c|}
\hline Characteristics & Frequency (n) & Percentage (\%) \\
\hline \multicolumn{3}{|l|}{ Education } \\
\hline No education & 14 & 7.9 \\
\hline Not Primary School graduate & 24 & 13.5 \\
\hline Primary School graduate & 37 & 20.8 \\
\hline Junior High School graduate & 22 & 12.4 \\
\hline Senior High School graduate & 53 & 29.8 \\
\hline University graduate & 28 & $15 \cdot 7$ \\
\hline \multicolumn{3}{|l|}{ Income } \\
\hline Low ( $\leq$ Rp 1,350,000) & 118 & 66.3 \\
\hline High $(\geq \operatorname{Rp} 1,350,000)$ & 60 & 33.7 \\
\hline \multicolumn{3}{|l|}{ The age at first sexual intercourse } \\
\hline$<18$ years old & 53 & 29.8 \\
\hline$\geq 18$ years old & 125 & 70.2 \\
\hline \multicolumn{3}{|l|}{ The number of sexual partner } \\
\hline$\leq 1$ partner & 150 & 84.3 \\
\hline$>1$ partner & 28 & 15.7 \\
\hline \multicolumn{3}{|l|}{ Body Mass Index } \\
\hline Normal (18.50 to 24.99$)$ & 103 & 57.9 \\
\hline Overweight (25.00 to 29.99 ) & 48 & 27 \\
\hline Obese $(\geq 30.00)$ & 27 & 15.2 \\
\hline \multicolumn{3}{|l|}{ Stress (Perceived Stress Scale) } \\
\hline Normal (0-7) & 51 & 28.7 \\
\hline Light (8-11) & 47 & 26.4 \\
\hline Standard (12-15) & 38 & 21.3 \\
\hline Heavy (16-20) & 26 & 14.6 \\
\hline $\operatorname{Big}(\geq 21)$ & 16 & 9 \\
\hline \multicolumn{3}{|l|}{ Genital hygiene } \\
\hline Not good $(<69)$ & 56 & 31.5 \\
\hline Good $(\geq 69)$ & 122 & 68.5 \\
\hline
\end{tabular}

Table 2. Biopsychosocial determinants and genital hygiene on cervical cancer

\begin{tabular}{|c|c|c|c|c|c|c|c|c|}
\hline \multirow{3}{*}{ Independent variables } & \multicolumn{4}{|c|}{ Cervical cancer } & \multirow{3}{*}{$\mathbf{O R}$} & \multicolumn{2}{|c|}{ 95\% CI } & \multirow{3}{*}{$\mathbf{p}$} \\
\hline & \multicolumn{2}{|c|}{ No } & \multicolumn{2}{|c|}{ Yes } & & \multirow{2}{*}{$\begin{array}{c}\text { Lower } \\
\text { limit }\end{array}$} & \multirow{2}{*}{$\begin{array}{l}\text { Upper } \\
\text { limit }\end{array}$} & \\
\hline & $\mathbf{n}$ & $\%$ & $\mathbf{N}$ & $\%$ & & & & \\
\hline \multicolumn{9}{|l|}{ Education } \\
\hline Low (<Senior high school) & 13 & (13.4) & 84 & $(86.6)$ & 0.02 & 0.01 & 0.05 & $<0.001$ \\
\hline High ( $\geq$ Senior high school) & 70 & $(86.4)$ & 11 & (13.6) & & & & \\
\hline \multicolumn{9}{|l|}{ Income } \\
\hline Low $(<\operatorname{Rp} 1,350,000)$ & 34 & (28.8) & 84 & $(71.2)$ & 0.09 & 0.04 & 0.19 & $<0.001$ \\
\hline High $(\geq \operatorname{Rp} 1,350,000)$ & 49 & $(81.7)$ & 11 & $(18.3)$ & & & & \\
\hline \multicolumn{9}{|c|}{ Age at first sexual intercourse } \\
\hline$<18$ years & 11 & (20.8) & 42 & $(79.2)$ & 0.19 & 0.09 & 0.40 & $<0.001$ \\
\hline \multirow{2}{*}{\multicolumn{9}{|c|}{ Sexual partner }} \\
\hline & & & & & & & & \\
\hline$\leq 1$ & 77 & (51.3) & 73 & (48.7) & 3.86 & 1.48 & 10.07 & 0.004 \\
\hline$>1$ & 6 & $(21.4)$ & 22 & (78.6) & & & & \\
\hline \multicolumn{9}{|l|}{ Body mass index } \\
\hline Normal $<25$ & 57 & $(55 \cdot 3)$ & 46 & (44.7) & 2.33 & 1.26 & $4 \cdot 31$ & 0.006 \\
\hline Overweight $\geq 25$ & 26 & $(34.7)$ & 49 & $(65.3)$ & & & & \\
\hline \multicolumn{9}{|l|}{ Stress } \\
\hline No & 32 & $(62.7)$ & 19 & (37.3) & 2.51 & 1.28 & 4.90 & 0.006 \\
\hline & 51 & $(40.2)$ & 76 & $(59.8)$ & & & & \\
\hline \multicolumn{9}{|l|}{ Hygiene of Genitalia } \\
\hline Poor $(<69)$ & 12 & (21.4) & 44 & (78.6) & 0.19 & 0.09 & 0.40 & $<0.001$ \\
\hline Good $(\geq 69)$ & 71 & $(58.2)$ & 51 & $(41.8)$ & & & & \\
\hline
\end{tabular}


Journal of Epidemiology and Public Health (2018), 3(2): 277-291

https://doi.org/10.26911/jepublichealth.2018.03.02.07

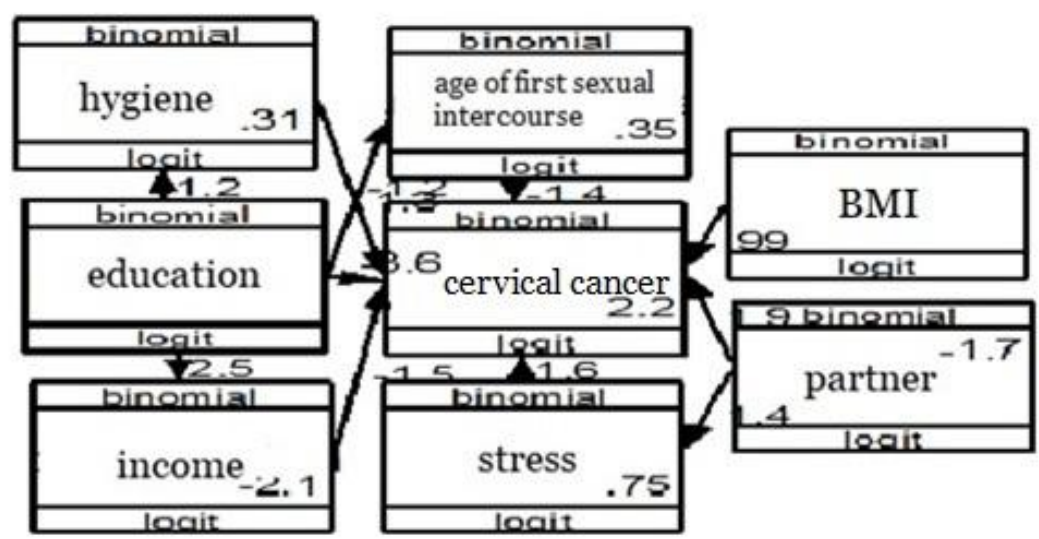

Figure 1. Structural Model with estimate

Table 3. The results of path analysis on the biopsychosocial and genital hygiene determinants on servical cancer

\begin{tabular}{|c|c|c|c|c|c|c|}
\hline \multirow[b]{2}{*}{$\begin{array}{l}\text { Dependent } \\
\text { Variables }\end{array}$} & & \multirow[b]{2}{*}{ Independent Variables } & \multirow[b]{2}{*}{$\mathbf{b}$} & \multicolumn{2}{|c|}{$95 \% \mathrm{CI}$} & \multirow[b]{2}{*}{$\mathbf{P}$} \\
\hline & & & & $\begin{array}{l}\text { Lower } \\
\text { Limit }\end{array}$ & $\begin{array}{l}\text { Upper } \\
\text { Limit }\end{array}$ & \\
\hline \multicolumn{7}{|l|}{ Direct Effect } \\
\hline Servical Cancer & $\leftarrow$ & Education & $-3 \cdot 58$ & $-4 \cdot 77$ & -2.39 & $<0.001$ \\
\hline Servical Cancer & $\leftarrow$ & Income & -1.49 & -2.73 & -0.25 & 0.019 \\
\hline Servical Cancer & $\leftarrow$ & $\begin{array}{l}\text { Age of First Sexual } \\
\text { Intercourse }\end{array}$ & -1.36 & -2.52 & -0.21 & 0.020 \\
\hline Servical Cancer & $\leftarrow$ & Number of partner & 1.90 & 0.31 & 3.49 & 0.019 \\
\hline Servical Cancer & $\leftarrow$ & Body Mass Index & 0.98 & -0.06 & 2.04 & 0.067 \\
\hline Servical Cancer & $\leftarrow$ & Stress & 1.59 & 0.39 & 2.80 & 0.009 \\
\hline \multicolumn{6}{|l|}{ Indirect Effect } & 0.028 \\
\hline Income & $\leftarrow$ & Education & 2.48 & 1.71 & 3.25 & $<0.001$ \\
\hline Genital Higyene & $\leftarrow$ & Education & 1.16 & 0.47 & 1.86 & 0.001 \\
\hline $\begin{array}{l}\text { Age of First Sexual } \\
\text { Intercourse }\end{array}$ & $\leftarrow$ & Education & 1.30 & 0.58 & 2.01 & $<0.001$ \\
\hline $\begin{array}{l}\text { Stress } \\
\text { n Observation }=178 \\
\text { Log Likelihood }=-44\end{array}$ & $\leftarrow$ & Number of partner & 1.36 & 0.12 & 2.61 & 0.032 \\
\hline
\end{tabular}

High-income women had a cervical cancer logit score of 1.49 units lower than in women with low incomes $(b=-1.49 ; 95 \%$ $\mathrm{CI}=-2.73$ to $-0.25 ; \mathrm{p}=0.019$ ).

There was a relationship between the first age of sexual intercourse with the decline of cervical cancer logs and is stated as statistically significant. Women who had first sexual intercourse $\geq 18$ years had a cervical cancer logit score of 1.36 units lower than in women who had sexual intercourse for the first time $<18$ years $(b=-$ $1.36 ; 95 \% \mathrm{CI}=-2.52$ to $-0.21 ; \mathrm{p}=0.020$ ).

There was a relationship between the number of sexual partners with the increase of cervical cancer logs and is stated as statistically significant. Women with more than 1 sexual partner had a cervical cancer logit score of 1.90 units higher than those of women with fewer sexual partners $\leq 1(\mathrm{~b}=$ $1.90 ; 95 \% \mathrm{CI}=0.31$ to $3.49 ; \mathrm{p}=0.019$ ). 
There was a relationship between the Body Mass Index (BMI) with an increase in cervical cancer $\operatorname{logs}$ and is stated as statistically nearly significant. Women with a BMI of more than normal had a cervical cancer logit score of 0.98 units higher than in women with normal BMI $(b=0.98 ; 95 \%$ $\mathrm{CI}=-0.06$ to $2.04 ; \mathrm{p}=0.067$ ).

There was a relationship between stress and the increase of cervical cancer logs and is stated as statistically significant. Women who had a perception of stress had a cervical cancer logit score of 1.59 units higher than in women who did not have a perception of stress $(b=1.59 ; 95 \% \mathrm{CI}=0.39$ to $2.80 ; \mathrm{p}=0.009$ ).

There was a relationship between genital hygiene and the decrease cervical cancer logit and is shown as statistically significant. Women who had good genital hygiene had a cervical cancer logit score of 1.24 units lower than women with poor genital hygiene $(b=-1.24 ; 95 \% \mathrm{CI}=-2.35$ to -0.13; $\mathrm{p}=0.028$ ).

There was a relationship between education and the increase of income logit and is shown as statistically significant. Women who had higher education had an income log score of 2.48 units higher than women with low education $(b=2.48$; 95\% $\mathrm{CI}=1.71$ to 3.25 ; $\mathrm{p}<0.001$ ).

There was a relationship between education and the increase of genital hygiene logit and is shown as statistically significant. Women who had higher education had a genetic scores score of 1.16 units higher than women with low education $(b=1.16 ; 95 \% \mathrm{CI}=0.47$ to $1.86 ; \mathrm{p}$ $=0.001$ ).

There is an association between education and the increase in the first-year logit of having sex $\geq 18$ years and is stated as statistically significant. Women who had higher education had a first-year logit score of having sex $\geq 18$ years of 1.30 units higher than women with low education $(b=1.30$; 95\% $\mathrm{CI}=0.58$ to $2.01 ; \mathrm{p}<0.001)$.

There is a relationship between the number of sexual partners and the increase of stress and is stated as statistically significant. Women who had more than 1 sexual partner had a stressful logit score of 1.36 units higher than women who had sexual partners $\geq 1(b=1.36 ; 95 \% \mathrm{CI}=0.12$ to $2.61 ; \mathrm{p}=0.032$ ).

\section{DISCUSSIONS}

\section{The relationship between educa- tion and cervical cancer}

Most of the cervical cancer patients are loweducated people. Perhaps this can be associated with low socioeconomic factors which will eventually lead to a young marriage and poor genital hygiene. Young marriage means having a greater possibility of getting a predisposing factor. Getting first coitus at a very young age can increase the possibility of intraepithelial neoplasia (Dahiya et al., 2017).

Damayanti (2013) in her study stated that there was a strong relationship between educational level and cervical cancer incident, where cervical cancer is more likely to occur to less-educated women than highly-educated women. The level of education is related to socioeconomic level, sexual activity, and hygiene. Low-educated women are less likely to care about their health especially for their genitals hygiene so that they will have a risk of cervical cancer (Aziz, 2006).

The result of this study showed that high education can decrease the risk of cervical cancer through income, age at first sexual intercourse, and genital hygiene. This study is supported by Sari et al. (2016), in the study, it is stated women's educational level will be able to affect the recipients of health information. The higher the level of education, the more infor- 
mation and knowledge gained. Low education causes a person to be indifferent to existing health programs, so they are unaware of the risks that will occur. This study is also in line with a study by Sharma \& Pattanshetty (2017), it is stated that loweducated women have 3.5 times higher risk of cervical cancer than highly educated women. A study by Reis et al. (2011) stated that high educational level reduces the risk of cervical cancer by 0.18 times. A study by Dahiya et al (2017) found about 61\% of the illiterate subjects. The low level of education can affect the genital hygiene and access to health facilities.

High education can increase family income with the jobs that require skills, understanding and good knowledge. The enhancement of knowledge will change a person's attitude in obtaining health services, able to do cancer screening and with high income, women will be able to do HPV vaccination. Genital hygiene behavior will get better with good attitude and knowledge. Highly educated women will prefer to postpone the sexual activity because they are busy with their work, therefore, they will not get married at young age.

\section{The relationship between income and cervical cancer}

The enhancement of cervical cancer is due to the lack of access to prevention services, screening, and treatments (Kessler, 2017). High incomes will make a person to more able to pay insurance and medicines, to buy more nutritious food, to get a better quality of children care and to live in the environment with supporting resources. On the other hand, a limited economy means making everyday life a struggle, therefore, they will have little time for a healthy lifestyle (Braveman \& Gottlieb, 2014).

This study is in line with a study by Sari et al. (2016) which stated that low incomes increased the risk of cervical cancer for about 3.4 times. A study which is conducted in India showed that the research subjects in the study by Dahiya et al (2017) mostly came from the middle class followed by a lower socioeconomic status. Some studies (Rajarao and Hemanth, 2012; Rai et al., 2012) found a higher frequency of cervical cancer in low socioeconomic class. This may be due to limited access to health services, low incomes, poor nutrition, poor hygiene and low awareness of health issues and precautions. All of these factors can increase the susceptibility to cervical cancer.

The result of this study showed that high income will decrease the incidents of cervical cancer. Women with higher income will be able to gain access to good quality of life such as health, hygiene, clean water and good nutrition. Women with higher income can easily do HPV vaccination in order to prevent cervical cancer.

\section{The relationship between the age at first sexual intercourse and cervical cancer.}

There was a relationship between early sexual intercourse and birth delivery at the young age. Women who give birth at the young age are most likely to have more sexual intercourse in their lifetime thus increasing their chances to be infected by Human Papilloma Virus (Ali et al., 2016; Makuza et al., 2015). A case study found that women who have their first sexual intercourse at $<18$ years old, had a higher chance of Cervical Squamous Cell Carcinoma. Women who have first sexual intercourse at an older age may be less exposed to HPV (Bassal et al., 2016; Sharma and Pattanshetty, 2017).

The result of this study is supported by several studies which showed that women who had first sexual intercourse 
under the age of 18 were at higher risk (almost 2 times) to get cervical cancer later in life than women over the age of 20. The first sexual intercourse is associated with HPV infection because a woman has been exposed to an infection from her partner (Dahiya et al., 2017). This study is in line with Sari et al. (2016), which stated that having sexual intercourse at a young age will lead to cervical cancer and the risk is 8 times higher.

Having sexual intercourse at a young age is associated with the transmission of HPV infection that can be transmitted from sexual partners and also frequent exposure to sexual intercourse in an early age. Genital HPV infection is associated with the development of cervical cancer. Based on the result of this study, it can be concluded that the age at first sexual intercourse of fewer than 18 years can increase the risk of cervical cancer.

\section{The relationship between the num- ber of sexual partners and cervical cancer}

A study by Bassal et al. (2016) stated that Depression or Anxiety may be associated with other risk factors that affect HPV, such as smoking and having sex with several partners, therefore, depression or anxiety may be a mediator and should not be a symptom of immediate risk. Depressed women are less likely to do routine Pap smear tests (Vigod et al., 2001) and can only be diagnosed after the occurrence of symptoms.

According to International Collaboration of Epidemiological Studies of Cervical Cancer (2006), having a sexual partner of more than one person is the risk factor of HPV. The development of cervical cancer is closely related to sexual behavior. The risk of cervical cancer will increase more than 10 times for women who have 6 or more sexual partners. Women who have multiple sex partners are susceptible to HPV and cervical cancer. This is because of the frequent exposure to various variants of the virus (Rajkumar et al., 2006).

Men who have had multiple partners either before or during the marriage can also increase the risk of cervical cancer (Hammouda et al., 2005). A husband with a history of multiple wives is related to cervical cancer in a study conducted by Bezabih et al. (2015) which stated that sexual behavior of male partners can be an important risk factor for cervical cancer in wives. In addition, women who have three or four sexual partners are at higher risk of developing cervical cancer than those with one or no partners.

Having more than one sexual partner will lead to the transmission of HPV virus because the transmission of genital HPV virus can be with sexual contact. A husband's sexual behavior can also be a risk factor for HPV virus transmission to his partner (wife). The number of sexual partners is also associated through the perception of stress in life that can increase the development of cancer cells in the cervix.

\section{The relationship between body mass index and cervical cancer}

A literature study conducted by Benedetto et al. (2015) showed the mechanism of the relationship between obesity and cancer through endogenous sex hormones, insulin resistance and hyperinsulinemia, adipokines, cytokines and chronic inflammation. Some studies stated that obesity is associated with the enhancement risk of cervical adenocarcinoma because cervical adenocarcinoma is a more hormonally responsive cancer. Furthermore, obese women have an enhancement in unbound estrogen, due to the reduced hepatic synthesis of sex hormone-binding globulins (Sex Hormone Binding Globulin/ SHBG). 
Journal of Epidemiology and Public Health (2018), 3(2): 277-291

https://doi.org/10.26911/jepublichealth.2018.03.02.07

This study is supported by a research done by Sari et al. (2016) which stated that women with an abnormal body mass index have 5.6 times higher risk of cervical cancer. The largest population-based study published so far proves a simple positive relationship between BMI and cervical cancer $(\mathrm{HR}=1.10 ; 99 \% \mathrm{CI}=1.03$ to 1.17$)$ (Bhaskaran et al., 2014). Poorolajal and Jenabi (2016) stated that Overweight is not associated with an increased risk of cervical cancer, but obesity has a weak association with an increased risk of cervical cancer.

Body Mass Index can affect the cancer cells through several mechanisms such as endogenous hormone with increased estrogen that can affect the development of cancer cells in the cervix. Obese women have an unbound estrogen enhancement, due to the lack of hepatic synthesis of sex hormone-binding globulins. Obesity and insulin resistance cause hyperglycemia, which supports the selection of severe cell clones that use glucose for the proliferation, contributing to apoptotic resistance, oncogenesis and tumor resistance to chemotherapy. Low adiponectin can lead to the severity of cervix, as well as cytokines and chronic inflammation that can also cause the severity of the cervix.

\section{The relationship between stress and cervical cancer}

Several studies have shown that stressors are associated with immune system dysregulation (Song et al., 2017). Natural Killer cell decreases in stress through the mechanism, especially decreases the lymphocyte proliferation and Natural Killer (NK) cell reduction. Natural Killer cell has an important role in immune functions, including defense mechanisms in virus and tumor cell infections.

Stress modulates the addition of $\mathrm{r}$ interferon and 2 interleukin in peripheral blood leukocytes. The addition of $y$ inter- feron and 2 interleukin lead to the reduction of NK-cells, macrophages, cytokines (IL 12, Tumor Necrosing Factor/ TNFa, Interferon/ IFN $\beta$ ), IL 10, Tumor Growth Factor/ TGF $\beta$ increased. This mechanism causes immune suppression, and it leads to the development of metastasis and the enhancement of infection risk (Jensen et al., 2007).

This study showed that stress is associated with the development of the cervical disease. According to Donghao Lu (2017), the Psychological pressure is associated with an increased risk of invasive cervical cancer through the enhancement of oncogenic infections, as well as the development of cervical cancer. Psychosocial factors may lead to a chronic immunosuppression condition, which may be conducive to HPV persistent and the development of cervical lesions (Green et al., 2013). Several studies suggested that immunosuppression, iatrogenic or autoimmune increase the risk of cervical cancer (Jensen et al., 2007).

Increased stressful life condition, sexual partners, stress and uncontrolled life condition, lack of social support, and weak coping styles are associated with an increased risk of abnormal cervical cytology (Fang et al., 2008). Other sources of stress such as discrimination, can also affect the risk of continuously HPV development. Other factors such as optimistic attitudes and social support, can minimize the impact of stress on immune function. In addition, stress can lead to depression, which will increase the psychosocial impact of immune function factors (Wilkerson et al., 2009).

The perception of stress on women as measured by the stress-perception scale developed by Cohen suggested that women with high-stress perceptions have the higher risk for cervical cancer. The mecha- 
nism of immunosuppression and also the reduction of Natural Killer cell in stress condition through the neuro endokrine mechanism. Lymphocyte proliferation and Natural Killer cells play an important role in immune function, including defense mechanisms in virus and tumor cell infections.

\section{The relationship between genital hygiene and cervical cancer}

The risk of CIN development in women who did not wash the vulva after sexual intercourse was 1.831 times greater than in women who cleaned the vulva (Wang et al., 2017).

This study showed that a history of genital infection is an increased risk of cervical cancer. Therefore, women are emphasized on personal hygiene and the use of barrier contraceptive methods such as condoms to help the primary prevention of sexually transmitted disease (Reis et al., 2011). The result of this study is in line with Sari et al. (2016) which suggested that poor genital hygiene may increase the risk of cervical cancer by 9 times and poor genetic hygiene causes the development of Candida albicans fungus. Candida itself is an infection caused by Candida fungus type of microorganisms. Candida vagina is a complex disease, if women cannot maintain their vaginal hygiene, then they will be infected with chronic candida. Candida albicans infection indicates the weakness of the immune system so that the body will lead to the growth of bacteria and the enhancement of cancer cells.

Studies which examine the reproductive health and genitalia by Shaw et al (2016) suggest that tampon use, previous gynecological infections, and cervical inflammation are associated with an enhancement risk of overall HPV infection. A study by Hinkula et al. (2004) showed that persistent HPV and Chlamydia tricho- monas infections can lead to the development of cervical cancer, therefore, good genital hygiene is needed.

Genital hygiene is an important thing that must be considered by women because poor genitalia hygiene will lead to the risk of cervical cancer. Infection of women genitalia which is caused by fungi and viruses such as Candida albicans, Chlamydia trichomonas, and Human Papilloma Virus (HPV) can be prevented by maintaining genitalia hygiene, such as the use of clean water, the frequency of changing the underwear, cleaning the vulva and also good sexual behavior, and it will reduce the risk of cervical cancer. Based on this study, it can be concluded that the direct effect of cervical cancer risk decreased with the enhancement of education, income, age at first sexual intercourse $\geq 18$ years old, and genital hygiene, while the risk of cervical cancer increased followed by increasing number of sexual partner, Body Mass Index and stress perception. The indirect effect of cervical cancer risk decreases with the enhancement of education through income, genital hygiene, and the age at first sexual intercourse.

\section{REFERENCES}

Ali CI, Makata NE, Ezenduko P (2016). Cervical Cancer: A Health Limiting Condition. Gynecology \& Obstetrics, 6(5): 378.

Aziz MF (2006). Skrining dan Deteksi Dini Kanker Serviks. (Eds): Ramli M, Umbas R, \& Panigoro SS. Fakultas Kedokteran Universitas Indonesia Jakarta: 97-100

Bassal R, Schejter E, Bachar R, Perri T, Jakobson-setton A, Ben-david LH, Cohen D. (2016). Risk Factors for Cervical Cancer and CIN3 in Jewish Women in Israel - Two Case Control Studies. Asian Pac J Cancer Prev, 17(4): 2067-2073. 
Journal of Epidemiology and Public Health (2018), 3(2): 277-291

https://doi.org/10.26911/jepublichealth.2018.03.02.07

Basu P, Mittal S, Bhadra Vale D, Chami Kharaji Y (2017). Secondary prevention of cervical cancer. Best Practice \& Research Clinical Obstetrics \& Gynaecology, 3: 1-13.

Benedetto C, Salvagno F, Canuto EM, Gennarelli G (2015). Obesity and female malignancies. Best Practice \& Research Clinical Obstetrics \& Gynaecology, 29(4): 528-540.

Bezabih M, Tessema F, Sengi H, Deribew A (2015). Risk Factors Associated with Invasive Cervical Carcinoma among Women Attending Jimma University Specialized Hospital, Southwest Ethiopia: A Case Control Study. Ethiopian Journal of Health Sciences, 25(4): 345352.

Bhaskaran K, Douglas I, Forbes H, et al. (2014) Body-mass index and risk of 22 specific cancers: a population-based cohort study of 5.24 million UK adults. Lancet,384:755-765.

Braveman P \& Gottlieb L. (2014). The Social Determinants of Health: It's Time to Consider the Causes of the Causes. $\mathrm{Pu}-$ blic Health Reports, 129(2), 19-31.

Bruni L, Barrionuevo-Rosas L, Albero G, Serrano B, Mena M, Gómez D, Muñoz J, Bosch FX, de S. S. (2017). Human Papillomavirus and Related Diseases Report, (May).

Chelimo C, Wouldes TA, Cameron LD, Elwood JM. (2013). Risk factors for and prevention of human papillomaviruses (HPV), genital warts and cervical cancer. Journal of Infection, 66(3): 207217.

Dahiya N, Bachani D, Acharya A., Sharma DN, Gupta S, Haresh KP (2017). SocioDemographic, Reproductive and Clinical Profile of Women Diagnosed with Advanced Cervical Cancer in a Tertiary Care Institute of Delhi. Journal of Obstetrics and Gynecology of India, 67(1):
$53-60$.

Damayanti IP (2013). Factors Associated with Cervical Cancer Incidence Arifin Achmad Hospital in Pekanbaru Year 2008-2010, jurnal Kesehatan Komunitas, 2(5): 88-93.

Fang CY, Miller SM, Bovbjerg DH, Bergman C, Edelson MI, Rosenblum NG, Bove BA, et al. (2008). Perceived stress is associated with impaired t-cell response to HPV16 in women with cervical dysplasia. Annals of Behavioral Medicine, 35(1): 87-96.

Ferlay J, Soerjomataram I, Ervik M, Dikshit R, Eser S, Mathers C et al. (2013). GLOBOCAN 2012 v1.o, Cancer Incidence and Mortality Worldwide: IARC CancerBase No. 11. Lyon, France: International Agency for Research on Cancer.

Green McDonald P, O'Connell M, Lutgendorf SK. (2013). Psychoneuroimmunology and cancer: A decade of discovery, paradigm shifts, and methodological innovations. Brain, Behavior, and Immunity, 30(SUPPL.): S1-S9.

Hammouda D, Muñoz N, Herrero R, Arslan A, Bouhadef A, Oublil M, Djedeat B, et al. (2005). Cervical carcinoma in Algiers, Algeria: Human papillomavirus and lifestyle risk factors. International Journal of Cancer, 113(3): 483-489.

Hinkula M, Pukkala E, Kyyrönen P, Laukkanen P, Koskela P, Paavonen J, Lehtinen. (2004). A population-based stu$\mathrm{dy}$ on the risk of cervical cancer and cervical intraepithelial neoplasia among grand multiparous women in Finland. British Journal of Cancer, 90(5): 1025-1029.

Hope KA, Moss E, Redman CWE, Sherman SM. (2017). Psycho-social influences upon older women's decision to attend cervical screening: A review of current evidence. Preventive Medicine, 101: 
$60-66$.

Jensen SE, Lehman B, Antoni MH, Pereira DB (2007). Virally mediated cervical cancer in the iatrogenically immunocompromised: Applications for psychoneuroimmunology. Brain, Behavior, and Immunity, 21(6): 758-766.

Kementrian Kesehatan RI Pusat Data dan Informasi Kesehatan (2015). Stop Kanker. Infodatin-Kanker, hal 3.

Kessler TA (2017). Cervical Cancer: Prevention and Early Detection. Seminars in Oncology Nursing, 33(2): 172-183.

Lowy DR, Solomon D, Hildeshein A, et al. (2008). Human Papiloma Virus Infection and the primary and secondary prevention of cervical cancer. Journal Cancer, 113: 93-98.

Lu Donghao (2017). The Role Of Psychological Stress In Cervical And Prostate Carcinogenesis. Department of Medical Epidemiology and Biostatistics Karolinska Institutet, Stockholm, Sweden

Makuza JD, Nsanzimana S, Muhimpundu MA, Pace LE, Ntaganira J, Riedel DJ. (2015). Prevalence and risk factors for cervical cancer and pre-cancerous lesions in Rwanda. The Pan African Medical Journal, 22, 26.

Murti B. (2016). Prinsip dan Metode Riset Epidemiologi. Program Studi Ilmu Kesehatan Masyarakat. Program Pascasarjana, Universitas Sebelas Maret: Yuma Pustaka.

Natphopsuk S, Settheetham-Ishida W, Sinawat $\mathrm{S}$, Pientong $\mathrm{C}$, Yuenyao $\mathrm{P}$, Ishida $\mathrm{T}$ (2013). Risk Factors for Cervical Cancer. Asian Pacific J Cancer Prev, 13(11): 5489-5495.

Plummer M, de Martel C, Vignat J, Ferlay J, Bray F, Franceschi S. (2016). Global burden of cancers attributable to infections in 2012: a synthetic analysis. The Lancet Global Health, 4(9): e609-e616.
Poorolajal J \& Jenabi E. (2016). The association between BMI and cervical cancer risk: A meta-analysis. European Journal of Cancer Prevention, 25(3): 232238.

Rai B, Khosla D, Patel F, et al. (2012). Palliative radiotherapy in advanced cancer of the cervix. Int J Pain, Symptom Control Palliat Care, 9(1). http://ispub.com/IJPSP/9/1/14291.

Rajarao P, Hemanth Kumar B. (2012). Study of socio demographic profile of cancer cervix patients in tertiary care hospital, Karimnagar (Andhra Pradesh). Int J Biol Med Res, 3(4): 23062310.

Rajkumar T, Cuzick J, Appleby P, Barnabas R, Beral V, Berrington De González A, et al. (2006). Cervical carcinoma and reproductive factors: Collaborative reanalysis of individual data on 16,563 women with cervical carcinoma and 33,542 women without cervical carcinoma from 25 epidemiological studies. International Journal of Cancer, 119(5): 1108-1124.

Reis N (2011). Risk Factors for Cervical Cancer: Results from a Hospital-Based Case-Control Study. International Journal of Hematology and Oncology, 21(3): 153-159.

Roy B, Tang TS. (2008). Cervical cancer screening in Kolkata, India: Beliefs and predictors of cervical cancer screening among women attending a women's health screening in Kolkata. India. J Cancer Edu, 23: 9-253.

Sari HE, Mudigdo A, Dermatoto A. 2016. Multilevel Analysis on the Social Determinants of Cervical Cancer in Yogyakarta. Journal of Epidemiology and Public Health, 1, (2):102-109. e-ISSN: 2549-0273

Sharma P, \& Pattanshetty SM. (2017). A study on risk factors of cervical cancer a- 
mong patients attending a tertiary care hospital: A case-control study. Clinical Epidemiology and Global Health.

Shaw E, Ramanakumar AV, El-Zein M, Silva FR, Galan L, Baggio ML, Villa LL, et al. (2016). Reproductive and genital health and risk of cervical human papillomavirus infection: Results from the Ludwig-McGill cohort study. BMC Infectious Diseases, 16(1): 1-10.

Song H. Saito E, Sawada N, Abe SK, Hidaka A, Shimazu T, Yamaji T, et al. (2017). Perceived stress level and risk of cancer incidence in a Japanese population: The Japan Public Health Center (JPHC)-based Prospective Study. Scientific Reports, 7(1): 1-10.

Torre L, Rebecca Siegel AJ. (2015). Global Cancer Facts \& Figures 3rd Edition. American Cancer Society, (800): 1-64.

Videbeck, S. L. (2008). Keperawatan Jiwa. Jakarta: EGC.

Vigod SN, Kurdyak PA, Stewart DE, Gnam WH, Goering PN. (2001). Depressive symptoms as a determinant of breast and cervical cancer screening in wo- men: a population-based study in Ontario, Canada. Arch Womens Ment Health, $14: 159-168$.

Wang Z, Wang J, Fan J, Zhao W, Yang X, $\mathrm{Wu} \mathrm{L}$, Li D, et al. (2017). Risk factors for cervical intraepithelial neoplasia and cervical cancer in Chinese women: Large study in Jiexiu, Shanxi Province, China. Journal of Cancer, 8(5): 924932.

Wilkerson JE, Bailey JM, Bieniasz ME, Murray SI, Ruffin MT. (2009). Psychosocial Factors in Risk of Cervical Intraepithelial Lesions. Journal of Women's Health, 18(4): 513-518.

World Health Organization. (2014). 2014b. Cancer Country Profiles, Indonesia. available on the WHO website (www.who.int). Accessed (10/9/2017)

(2016). Human Pappiloma virus (HPV) and Cervical Cancer. on http://www.who.int/mediacentre/factsheets/fs38o/en/.

(2017). Cancer. available on http://www.who.int/mediacentre/factsheets/fs297/en/ 